Original Research Paper

\title{
The Role of Oxidative Stress during Pregnancy on Obstetric Pathology Development in High-Yielding Dairy Cows
}

\author{
${ }^{1}$ Inna Ventsova and ${ }^{2}$ Vladimir Safonov \\ ${ }^{1}$ Department of Private Animal Husbandry, \\ Voronezh State Agricultural University Named After Emperor Peter the Great, Voronezh, Russia \\ ${ }^{2}$ Laboratory of Environmental Biogeochemistry, \\ Vernadsky Institute of Geochemistry and Analytical Chemistry of Russian Academy of Sciences, Moscow, Russia
}

\section{Article history}

Received: 07-12-2020

Revised: 15-01-2021

Accepted: 18-01-2021

Corresponding Author:

Inna Ventsova

Department of Private Animal

Husbandry, Voronezh State

Agricultural University Named

After Emperor Peter the Great,

Voronezh, Russia

Email: ventsovair668@ rambler.ru

\begin{abstract}
The study aimed to examine the processes of oxidative stress and their intensity depending on the state of the antioxidant system in dairy cows. The study was conducted in 2018-2019 on the territory of the Druzhba breeding factory (Voronezh region, Russia) and involved 154 cows divided into 4 groups. Group 1 consisted of healthy animals $(n=83)$. Group 2 contained animals with afterbirth retention $(n=6)$. Group 3 included animals with uterine subinvolution $(n=49)$. Group 4 comprised animals with postpartum catarrhal-purulent endometritis $(n=16)$. The blood samples were taken from the animals to estimate the content of vitamin E, lipids, malonic aldehyde and enzymes-catalases, reductase and ferroxidase. The concentration of vitamin $\mathrm{E}$ in groups 1 and 4 were found to decrease (by $3.9-23.2 \% ; 30.7 \pm 2.16-25.9 \pm 2.16$ compared to $31.9 \pm 1.68$ $\mu \mathrm{M} / \mathrm{L}$ ) within two months. The level of malonic aldehyde in group 4 was higher than in other groups after the first month. In one month, its level increased by $20.6 \%(1.11 \pm 0.09 \mu \mathrm{M} / \mathrm{L})$ by $35.4,19.4$ and $6.7 \%$, respectively $(\mathrm{P}<0.01-0.001)$. The exhibited differences indicate the strong significance of functional insufficiency of the antioxidant protection system during the development of oxidative stress during pregnancy and, as a result, the etiology and pathogenesis of parturient and postpartum complications in cows.
\end{abstract}

Keywords: Antioxidant Protection, Cows, Obstetric Pathology, Oxidative Stress, Pregnancy

\section{Introduction}

The creation of high-yielding livestock is one of the great accomplishments of human society, achieved at the turn of the twentieth and twenty-first centuries. The high productivity of these animals can be attributed to the intensity of the metabolic processes in their bodies and the intense functional activity of all of their organs and systems, which can lead to the development of numerous pathological conditions in the body, including those that affect reproductive functions. The obstetric and gynaecological pathology of livestock continues to be one of the main factors that restrains both their growth and productivity. In this respect, pregnancy and parturition can be considered the most vulnerable periods of the animals' lives.

Pregnancy causes physiological stress for any organism (Dobson and Smith, 2000). This period is characterized by the intense performance of all metabolic processes, including free radical oxidation, which is constrained by the antioxidant defense system. Molecular Oxygen $\left(\mathrm{O}_{2}\right)$, which participates in oxidase (mitochondrial) and oxygenase (microsomal) oxidation reactions, is especially important in FRO processes. During the gradual recovery of this molecule, its activated forms arise, which is one of the main and critical stages in the initiation and potentiation of Lipid Peroxidation (LPO) reactions. The superoxide anion radicals $\left(\mathrm{O}_{2}\right)$, Hydroperoxide Radicals $\left(\mathrm{HO}_{2}\right)$, Hydrogen Peroxide $\left(\mathrm{H}_{2} \mathrm{O}_{2}\right)$ and singlet Oxygen $\left(\mathrm{O}_{2}\right)$ are formed. These Reactive Oxygen Species (ROS) undergo oxidation reactions with polyunsaturated lipids, including fatty acid phospholipid residues-the main structural components of biological membranes. The reactions initiate the formation of multiple primary, secondary and final molecular products of LPO, such as peroxide Radicals $\left(\mathrm{RO}_{2}\right)$, which play an important role in the structural modification of biomembranes and changes in their physicochemical properties. These molecules change the phase state of the lipid biolayer, increase cell surface hydration and modify the membrane receptivity for ions of small molecules. The 
use of LPO products formed in the cells' metabolic apparatus is believed to be a form of evolutionary adaptation of living systems to oxygen since it is impossible to completely avoid their formation due to the spontaneous nature of such reactions. Free radicals are involved in electron transfer, cell membrane renewal and cell birth and death and participate in the process of ovulation and fertilization (Kireev et al., 2018).

At the same time, excessive production of ROS by granulocytes and blood monocytes, tissue macrophages that produce these molecules during the interruption of complex processes of their utilization, initiates excessive accumulation of LPO products in the body's cells. These changes lead to oxidative stress, dissociation of oxidative phosphorylation in the mitochondria, disruption of microsomal oxidation, changes in the structural organization of chromatin, distortions in the interpretation of genetic information by the cell and the subsequent disruption of the permeability and structural integrity of the cell's biomembrane. Thus, these reactions underlie the development of oxidative stress and, as a result, pathological processes in the body, which lead to various diseases. The cell structures that are damaged-the DNA or the outer membrane-are what ultimately determine the disease development as well as its severity (Halliwell et al., 1992; Safonov et al., 2014).

Protection against the damaging effects of ROS and LPO products is carried out by a multicomponent system of antioxidants, including enzymatic (superoxide dismutase, catalase, glutathione peroxidase, etc.) and non-enzymatic (vitamins $\mathrm{E}$ and $\mathrm{C}$, carotene, glutathione, ceruloplasmin, albumin, etc.) elements. The Antioxidant Defence system (AOD) limits the processes of FRO of lipids in virtually all of its aspects and supports this class of reactions at a relatively constant level. This system controls the level of ROS, free radicals and molecular products of LPO in the body, plays a crucial role in maintaining the body's homeostasis when it interacts with the changing conditions of the internal and external environments and ensures the body's viability (Kunwar and Priyadarsini, 2011).

Among dairy cows, the mortality of embryos at an early stage of pregnancy is quite common. This pathology is known to occur in every third to the fifth case (from 20 to $40 \%$, according to different data) and is directly related to the level of milk production in cows (Pascottini et al., 2020a). In particular, some data suggests that in cows with a milk production level of up to 6 thousand $\mathrm{kg}$, the frequency of embryonic mortality is onethird $(33 \%)$, in those with 6 to 7 thousand $\mathrm{kg}$-almost half $(43 \%)$ and from 7 thousand $\mathrm{kg}$, the embryo mortality rate is high in most cows $(67 \%)$ (Pezeshki et al., 2010).

Due to the increase in dairy productivity of cows, which in recent decades has increased from 4000-5000 to $8000-11000 \mathrm{~kg}$, the percentage of fertilized cows has halved, from 60-65 to 30-35\% (Mezzetti et al., 2020). Such trends are overlapping, i.e., an increase in the mortality rate of potential breeding and a decrease in fertility (the number of fertilized cows) will lead to an inevitable decrease in the total population, as well as the quality of future generations. Thus, the price for raising the milk yield is too high. However, this problem can be solved by finding solutions to reduce embryonic mortality. It implies assessing the factors determining maternal risk concerning embryonic mortality.

Thus, embryonic mortality becomes a serious problem as it harms the health of the cow and can lead to death. Moreover, due to physiological stress, the level of milk production can decrease until complete disappearance. The death of an embryo provokes the changes in a cow's body to occur at the level of endocrine and immune systems, as well as incites metabolic disorders (Pascottini et al., 2020b).

Also, the infertility of cows remains a serious issue, which may be associated with delayed postpartum. This pathology refers to complications arising in the third stage of childbirth. Causes leading to delayed postpartum and infertility include vitamin and micronutrient deficiencies, nutritional deficiencies, insufficient dynamics of fetal development in the late period of pregnancy, as well as abrupt changes in microclimatic conditions due to any external causes, such as changes in the keeping conditions. Among the calved cows, delayed postpartum may occur in $10-40 \%$ of cases (Sordillo and Mavangira, 2014). This pathology may also be caused by abnormalities, in particular, excessive free radical activity.

The postpartum period in dairy cows is associated with a high risk of developing diseases. This primarily concerns the reproductive system. In this case, it is important to regulate the immune response in the uterus. The consequences of the abnormal immune response may be the inflammation of the reproductive tract. Conditions such as metritis, purulent vaginal discharge and subclinical endometritis can be seen in half of postpartum dairy cows. These conditions are associated with injuries to the birth canal accompanied by bacterial infection in the uterus (Pascottini et al., 2019).

In this regard, the identification of developmental factors of pathology during pregnancy, parturition and the postpartum period in high-yielding cows (Karpenko et al., 2018; Nezhdanov and Dashukaeva, 1999), which is largely due to the disturbance of metabolic processes in their bodies, continues to be relevant. The goal of this study was to analyse the processes of oxidative stress formation in relation to the state of the antioxidant defence system of the body in highyielding dairy cows during the dry period and after parturition, taking into account the development of obstetric pathology. The results of this research can be used to study protective physiological mechanisms on farm animals as a model object in the localization of free radicals. 


\section{Materials and Methods}

The study was conducted on cows of the red-motley breed belonging to the "Druzhba" breeding plant in the Voronezh region of the Russian Federation in 2018-2019. Experiments were conducted in the winter-stall period (October-April). Average milk productivity in the herd was 6.5 thousand $\mathrm{kg}$ per year and conditions of keeping corresponded to the pegging-pasturing method.

All animals were grown on the same farm, kept in identical conditions, fed the same food, in the same quantity and received the same water. Fodder corresponded to $100 \%$ in terms of nutrition, protein and sugar-98\%, calcium and phosphorus-72\% and carotene-91\%. Feed composition was the following: Corn silage, cooking salt, treacle, hay from meadow herbs, straw from spring crops, as well as concentrated feed.

\section{Criteria for the Formation of Animal Groups}

Using obstetric-gynaecological studies of cows as a basis, four groups were formed: The first group had healthy animals $(n=83)$; the second group contained animals with parturient pathology in the form of afterbirth retention $(n=6)$; the third group had animals with pathology of the postpartum period in the form of uterine subinvolution ( $n=49$ ); and the fourth group comprised animals with pathology of the postpartum period in the form of postpartum catarrhal-purulent endometritis $(n=16)$. During the dry period, animals of the studied groups were considered conditionally healthy and conditionally sick.

\section{Study Design}

Blood that was used in the research was taken from the jugular vein two months, one month, two weeks and one week before parturition and one, two, three, four and more weeks after parturition. Animals that were involved in the experiments were constantly monitored. Their overall condition, the progression of pregnancy, postpartum involutional processes in the genital organs and the timing of their completion were all taken into account (Sheldon et al., 2006).

\section{Metabolic Blood Indices Determined in the Work}

Transrectal palpation was applied to determine the functional state of the sexual reproduction organs. Blood analysis was performed by taking samples from the jugular vein in the morning, using heparin as an anticoagulation agent.

To assess the intensity of Lipid Peroxidation (LPO) and the state of the Antioxidant Defence system (AOD) of the body in the blood and serum, the content of malondialdehyde, catalase activity, glutathione reductase activity, ferroxidase activity and the contents of vitamin $\mathrm{E}$ and carotene were determined according to generally accepted methods. The content of vitamins was determined using the spectrophotometric method, while the lipid content was determined employing Lachema kits (Czech Republic).

\section{Mathematical Data Processing}

Quantitative indicators were recorded using the mean (M) and standard deviation (m), representing the data as M $\pm \mathrm{m}$. Experimental data processing was carried out using mathematical statistical methods, as accepted in biology and medicine, using the computer software "Statistica 6.0". The differences at $(\mathrm{p} \leq 0.05)$ were considered statistically significant. The Student's T-criterion was used to check differences between groups.

\section{Results}

Analysis of the LPO-AOD state in the bodies of cows with a normal postpartum period and in animals with obstetric pathology (Tables 1 and 2) indicated that just two months before calving, the latter showed reduced intensity of both non-enzymatic and enzymatic parts of the AOD system. This finding is evidenced by lower blood levels of all bio-oxidants: Vitamin E (by $3.9-23.2 \%$, Table 1), carotene (by 17.8-32.2\%; Table 1), catalase activity (by 5.7-10.1\%; Table 1), glutathione reductase (by 2.3-5.5\%; Table 1) and ceruloplasmin (by 3.9-5.7\%; Table 1). At the same time, before parturition, the lowest level of vitamin $\mathrm{E}$ was detected in the fourth group, which was lower than the first three by $26.5 \%$, 12.1 and 19.0. Moreover, during this period, the vitamin $\mathrm{E}$ content in the third group was higher than in the second by $8.5 \%$. A similar tendency was observed with respect to catalase activity-a week before parturition in animals of the fourth group, it was lower than that in the first three by $12.0,4.2$ and $6.8 \%$. At the same time, the level was lower in animals of the second group than in animals of the third by $2.7 \%$. For ceruloplasmin, the following can be reported: A week before calving in the third and fourth groups, its level increased by 8.2 and $3.6 \%$, respectively and the lowest level was noted in the second group of animals, which was lower than the other groups by 7.3, 10.0 and 5.6\% (Table 2).

The consequence of a reduced functional state of the systems that control the intensity of LPO processes is a higher malondialdehyde content in the blood $(0.90 \pm 0.05$ $1.04 \pm 0.03$ compared to $0.74 \pm 0.02 \mu \mathrm{M} / \mathrm{L})$. However, in the fourth group, the peroxidation processes during all periods of studies prior to parturition were the most pronounced. Two months before parturition, the malondialdehyde content was $0.92 \pm 0.03 \mu \mathrm{M} / \mathrm{L}$, which was higher by $24.3 \%$ than that of the animals of the first group, higher by $2.2 \%$ than that of the second group and lower than that in the third group by $11.5 \%$. 
Table 1: Indicators of malondialdehyde and the state of the antioxidant system in the bodies of clinically healthy and sick cows during the prenatal period

\begin{tabular}{|c|c|c|c|c|}
\hline \multirow[b]{2}{*}{ Indicator } & \multicolumn{4}{|c|}{2 months before parturition } \\
\hline & $\begin{array}{l}\text { Group } 1 \\
\text { (Clinically healthy } \\
\text { animals) }\end{array}$ & $\begin{array}{l}\text { Group } 2 \\
\text { (Animals with } \\
\text { afterbirth retention) }\end{array}$ & $\begin{array}{l}\text { Group } 3 \\
\text { (Animals with } \\
\text { subinvolution } \\
\text { of the uterus) }\end{array}$ & $\begin{array}{l}\text { Group } 4 \\
\text { (Animals with } \\
\text { postpartum } \\
\text { endometritis) }\end{array}$ \\
\hline Malondialdehyde, $\mu \mathrm{M} / \mathrm{L}$ & $0.74 \pm 0.02$ & $0.90 \pm 0.05$ & $1.04 \pm 0.03$ & $0.92 \pm 0.03$ \\
\hline Vitamin $\mathrm{E}, \mu \mathrm{M} / \mathrm{L}$ & $31.9 \pm 1.68$ & $30.7 \pm 2.16$ & $28.3 \pm 0.96$ & $25.9 \pm 2.16$ \\
\hline Carotene, $\mu \mathrm{M} / \mathrm{L}$ & $4.97 \pm 0.87$ & $4.22 \pm 0.94$ & $4.00 \pm 0.11$ & $3.76 \pm 0.08$ \\
\hline Ceruloplasmin, $\mu \mathrm{M}$ benzoquinone $/ \mathrm{L} \cdot \min$. & $317.4 \pm 12.41$ & $320.1 \pm 10.00$ & $305.6 \pm 15.65$ & $300.2 \pm 10.41$ \\
\hline Catalase activity, $\mu \mathrm{M} \mathrm{H}_{2} \mathrm{O}_{2} / \mathrm{L} \cdot \min \cdot 10^{3}$ & $36.9 \pm 4.08$ & $37.5 \pm 3.29$ & $34.9 \pm 2.15$ & $33.5 \pm 0.65$ \\
\hline Glutathione reductase activity, $\mu \mathrm{M}$ G-SS-G/L-min. & $440.2 \pm 10.06$ & $430.1 \pm 18.88$ & $429.1 \pm 10.15$ & $417.3 \pm 13.13$ \\
\hline
\end{tabular}

Table 2: Indicators of malondialdehyde and the state of the antioxidant system in the bodies of clinically healthy and sick cows during the prenatal period

\begin{tabular}{|c|c|c|c|c|}
\hline \multirow[b]{2}{*}{ Indicator } & \multicolumn{4}{|c|}{1 week before parturition } \\
\hline & $\begin{array}{l}\text { Group } 1 \\
\text { (Clinically } \\
\text { healthy animals) }\end{array}$ & $\begin{array}{l}\text { Group } 2 \\
\text { (Animals with } \\
\text { afterbirth retention) }\end{array}$ & $\begin{array}{l}\text { Group } 3 \\
\text { (Animals with } \\
\text { subinvolution } \\
\text { of the uterus) }\end{array}$ & $\begin{array}{l}\text { Group } 4 \\
\text { (Animals with } \\
\text { postpartum } \\
\text { endometritis) }\end{array}$ \\
\hline Malondialdehyde, $\mu \mathrm{M} / \mathrm{L}$ & $0.93 \pm 0.03 *$ & $1.16 \pm 0.01 *$ & $1.13 \pm 0.01 *$ & $1.18 \pm 0.08 *$ \\
\hline Vitamin $\mathrm{E}, \mu \mathrm{M} / \mathrm{L}$ & $23.8 \pm 2.40^{*}$ & $19.9 \pm 0.90^{*}$ & $21.6 \pm 0.72 *$ & $17.5 \pm 1.6^{*}$ \\
\hline Carotene, $\mu \mathrm{M} / \mathrm{L}$ & $3.96 \pm 0.49$ & $3.85 \pm 0.47$ & $3.74 \pm 0.21$ & $3.89 \pm 0.03$ \\
\hline Ceruloplasmin, $\mu \mathrm{M}$ benzoquinone/L· min. & $284.3 \pm 11.08$ & $263.2 \pm 11.33$ & $292.3 \pm 14.44$ & $278.1 \pm 10.12$ \\
\hline Catalase activity, $\mu \mathrm{M} \mathrm{H}_{2} \mathrm{O}_{2} / \mathrm{L} \cdot \min \cdot 10^{3}$ & $30.9 \pm 1.28$ & $28.4 \pm 1.10 *$ & $29.2 \pm 2.10 *$ & $27.2 \pm 1.12 *$ \\
\hline Glutathione reductase activity, $\mu \mathrm{M}$ G-SS-G/L-min. & $420.2 \pm 10.57$ & $389.4 \pm 19.18$ & $402.4 \pm 11.25$ & $392.7 \pm 18.15$ \\
\hline
\end{tabular}

Note: *-P<0.01-0.001

In one month, its level increased by $20.6 \%(1.11 \pm 0.09$ $\mu \mathrm{M} / \mathrm{L})$, which was higher than in the other groups by $35.4,19.4$ and $6.7 \%$, respectively $(\mathrm{P}<0.01-0.001)$. Two weeks before parturition, the malondialdehyde concentration in the animals' blood of the fourth group increased to $1.13 \pm 0.01 \mu \mathrm{M} / \mathrm{L}$ and during parturition, it was $1.18 \pm 0.08 \mu \mathrm{M} / \mathrm{L}$, which was $28.3 \%$ higher than the initial figure. A week before parturition, the content remained higher in the fourth group than in the previous three groups and the difference in this indicator was 26.9, 1.7 and 4.4\% $(\mathrm{P}<0.01-0.001)$.

Therefore, during the prenatal period, the strength of the antioxidant system was diminished in all animals with obstetric pathology and this change was most pronounced in the group of animals with postpartum endometritis. This finding suggests that favourable conditions for the development of disease are created as early as the stage of pregnancy as a result of the stressful nature of parturition itself, as well as due to certain insufficiencies of the antioxidant system during the prenatal period. Generally, lower indicators of the antioxidant system in animals with subsequently arising obstetric pathology can be used in prognostic strategies for the prevention of these diseases.

Prenatal oxidative stress, which leads to the activation of LPO processes and significant changes in the functional state of the AOD system, also affects the postpartum period. A week after parturition, in healthy animals, the blood content of malondialdehyde increased by $10.8 \%$ compared to the prenatal period $(1.03 \pm 0.04$ compared to $0.93 \pm 0.03 \mu \mathrm{M} / \mathrm{L}$ ) and in sick animals, the average change was $10.2 \%$ (data in Table $3 \mathrm{Vs}$ data in Table 2). The indicators of the latter exceeded the rate of healthy animals by $6.8-26.2 \%$. The highest concentration of malondialdehyde during the early postpartum period was recorded in the blood of cows of the second group, which showed changes of $26.2 \%$ $(\mathrm{P} \pm 0.001), 18.2 \%(\mathrm{P} \pm 0.001)$ and $4.8 \%$.

Changes in the AOD system during the early postpartum period were manifested by a decrease of vitamin $E$ content in the blood of healthy cows by $40 \%$ (Tables 2 and 3) and in sick cows by 8.7-38.2\% (Table 3 ); carotene showed changes in healthy and sick cows by $12.5 \%(3.52 \pm 0.37$ compared to $3.96 \pm 0.49 \mu \mathrm{M} / \mathrm{L})$ and $5.1-14.7 \%$ (3.26 $\pm 0.55-3.70 \pm 0.11$ compared to $3.74 \pm 0.21-$ $3.89 \pm 0.03 \mu \mathrm{M} / \mathrm{L})$, respectively; catalase activity showed changes in healthy and sick cows by $11.2 \%$ (Tables 2 and 3 ) and 1.7-9.2\% (Tables 2 and 3), respectively; and glutathione reductase showed changes in healthy and sick cows by $6.5 \% \quad(394.3 \pm 12.14$ compared to $420.2 \pm 10.57 \mu \mathrm{M} \quad \mathrm{G}-\mathrm{SS}-\mathrm{G} / \mathrm{L} \cdot \mathrm{min})$ and $5.8-13.3 \%$ $(343.7 \pm 12.75-380.1 \pm 12.78$ compared to $389.4 \pm 19.18$ - 
402.4 $\pm 11.25 \mu \mathrm{M}$ G-SS-G/L·min), respectively. As for the ferroxidase activity of ceruloplasmin, in animals with obstetric pathology, a decreased trend was observed, while in cows with a normal postpartum period, on the contrary, an increase of $12.7 \%$ was observed (from $284.3 \pm 11.08$ to $320.3 \pm 10.56 \mu \mathrm{M}$ benzoquinone/L.min, $\mathrm{P}<0.05)$. This change likely allows the adequate control of LPO activity and the prevention of the development of pathological processes.

With the completion of postpartum involution of the genital organs, blood from the healthy animals showed that the strength of all controlled AOD parameters increased significantly and the content of secondary LPO products decreased by $21.2 \%$ ( $\mathrm{P}<0.001)$ (Tables 3 and 4$)$. In cows with parturient pathology, during this period, the malondialdehyde content in the blood exceeded that of healthy animals by $41.2-56.5 \% \quad(1.20 \pm 0.03-1.33 \pm 0.08$ compared to $0.85 \pm 0.04 \mu \mathrm{M} / \mathrm{L}, \mathrm{P}<0.001)$. However, the malondialdehyde content in the blood of healthy cows was lowest during the entire postpartum period and the highest malondialdehyde content was observed in the group of cows with postpartum endometritis.

Table 3 shows changes in the concentration of various substances across different groups. For instance, the malonic aldehyde content significantly increased in the afterbirth retention group $(\mathrm{p} \leq 0.01)$. The afterbirth retention group showed the lowest content of vitamin $\mathrm{E}$ $(\mathrm{p} \leq 0.001)$ and the lowest level of catalase activity $(\mathrm{p} \leq 0.01)$. The lowest benchoquinone content was found in animals with afterbirth retention and postpartum endometritis $(\mathrm{p} \leq 0.001)$.

Additionally, for cows with obstetric pathology, lower levels of bio-oxidant contents and activities were observed: Vitamin (E 16.3 $\pm 1.44-23.3 \pm 1.68$ compared to $28.1 \pm 2.4 \mu \mathrm{M} / \mathrm{L})$ in healthy animals, carotene (3.48 $\pm 0.22-3.68 \pm 0.10$ compared to $4.16 \pm 0.42$ $\mu \mathrm{M} / \mathrm{L}), \quad$ catalase activity $\quad(28.6 \pm 0.81-31.1 \pm 1.76$ compared to $35.8 \pm 3.54 \mu \mathrm{M} \quad \mathrm{H}_{2} \mathrm{O}_{2} / \mathrm{L} \cdot \mathrm{min} \cdot 10^{3}$ ), glutathione reductase $(379.1 \pm 11.46-383.9 \pm 13.77$ compared to $407.5 \pm 10.97 \mu \mathrm{M}$ G-SS-G/L.min) and ceruloplasmin $(289.5 \pm 11.64-315.3 \pm 19.83$ compared to $318.6 \pm 11.08 \mu \mathrm{M}$ benzoquinone $/ \mathrm{L} \cdot \min )$.

Thus, the early postpartum period in animals with obstetric pathology is characterized by the activation of lipid peroxidation processes and a decrease in the functional state of the antioxidant system. Moreover, this change is most clearly manifested in cows with afterbirth retention. Later, the intensity of lipid peroxidation in their blood decreased and the antioxidant system potential began recovering but still did not reach the same level as in healthy animals.

In cows with subinvolution of the uterus, the peroxidation processes progressed more intensively until the second week and in cows with postpartum endometritis, these processes progressed until the third week after parturition. Only at a later time after parturition did their levels begin to decline.

Table 3: Levels of malondialdehyde in the blood and antioxidant system indicators after parturition in healthy cows and in cows with obstetric pathology

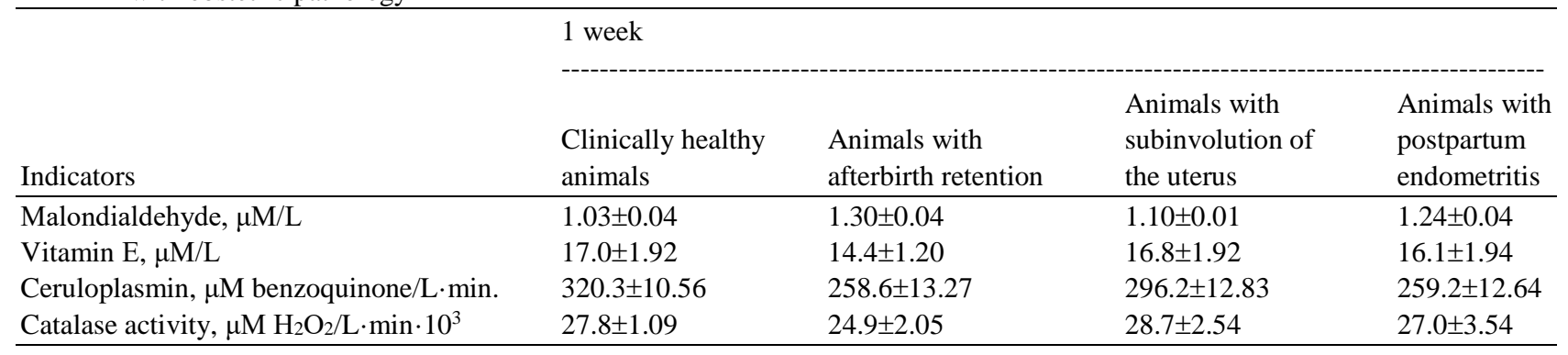

Table 4: Levels of malondialdehyde in the blood and antioxidant system indicators after parturition in healthy cows and in cows with obstetric pathology

\begin{tabular}{|c|c|c|c|c|}
\hline \multirow[b]{2}{*}{ Indicators } & \multicolumn{4}{|l|}{4 and more weeks } \\
\hline & $\begin{array}{l}\text { Clinically healthy } \\
\text { animals }\end{array}$ & $\begin{array}{l}\text { Animals with } \\
\text { afterbirth retention }\end{array}$ & $\begin{array}{l}\text { Animals with } \\
\text { subinvolution of } \\
\text { the uterus }\end{array}$ & $\begin{array}{l}\text { Animals with } \\
\text { postpartum } \\
\text { endometritis }\end{array}$ \\
\hline Malondialdehyde, $\mu \mathrm{M} / \mathrm{L}$ & $0.85 \pm 0.04 *$ & $1.09 \pm 0.03 *$ & $1.20 \pm 0.03 *$ & $1.33 \pm 0.08$ \\
\hline Vitamin $\mathrm{E}, \mu \mathrm{M} / \mathrm{L}$ & $28.1 \pm 2.40^{*}$ & $19.2 \pm 0.48^{*}$ & $22.3 \pm 1.68^{*}$ & $16.3 \pm 1.44$ \\
\hline Ceruloplasmin, $\mu \mathrm{M}$ benzoquinone $/ \mathrm{L} \cdot \min$. & $318.6 \pm 11.08$ & $310.4 \pm 14.02$ & $315.3 \pm 19.83$ & $289.5 \pm 11.64$ \\
\hline Catalase activity, $\mu \mathrm{M} \mathrm{H}_{2} \mathrm{O}_{2} / \mathrm{L} \cdot \min \cdot 10^{3}$ & $35.8 \pm 2.00 *$ & $30.1 \pm 1.08 *$ & $31.1 \pm 1.76$ & $28.6 \pm 0.81$ \\
\hline
\end{tabular}


The antioxidant system in such animals suffers to an even greater degree, especially its enzymatic elements, which show changes only two to three weeks after parturition. The non-enzymatic element show changes somewhat earlier and thus, there is a decrease in the level of lipid peroxidation products in blood from sick cows.

\section{Discussion}

Negative effects of oxidative stress on the embryo development dynamics are determined by several factors: (a) The direct effect of free radicals, leading to an increase in the level of toxins; (b) the influence of free radicals on the hormone synthesizing structures of the glands and immunocompetent system of the body (Pascottini et al., 2019).

Among other factors that can lead to reproductive failure of the cow's sexual system, vaginal microflora plays a major role. The latter determines the norm in providing homeostasis of the genital organs and their resistance to the settlement of pathogens. Representatives of normal microflora include lactic bacteria and bifidobacteria as they are antagonists of microorganism species that are conditionally pathogenic and pathogenic. Besides, normal microflora inhibits the growth and multiplication of pathogenic and conditionally pathogenic ones. This protective effect of lactic bacteria and bifidobacteria is associated with the secretion of lactic and other organic acids in large quantities, as well as various bacteriocins, vitamins and other biologically active substances that slow or stop the growth of pathogenic microflora (LeBlanc, 2010). Also, lactobacteria have a direct stimulating effect on the immunocompetent structures of the reproductive tract. It follows that the resistance of vaginal microflora depends on the coordinated action of the endocrine and immune systems.

The violation of endocrine or immune system function incites the occurrence of dysbiosis occurs, which results in normal microflora being replaced by conditionally pathogenic and pathogenic one. Thus, among many factors determining the probability of early embryo death in lactating cows, deficiency and imbalance of essential mineral elements, as well as oxidative stress and endogenous intoxication, which develops against the background of microelement deficiency, prevail. Further development of intoxication and oxidative stress processes leads to endocrine and immune insufficiency. The latter is accompanied by disorders in immune and trophic mother-nucleus relations (Havekes et al., 2020). Correction of diselementosis, antioxidant, endocrine and immune status of cow-mothers should be the basis for the development of tools and methods to prevent embryo loss and address the problem of fertility in highly productive dairy cattle breeding.

The activity of the synthesis of sex hormones in the body is directly related to the level of NO. In case of violation of hormones synthesizing function of the ovaries, the level of NO decreases. Moreover, a low concentration of NO can determine the violations of the generative function performed by gonads. Such an effect is primarily since their ovulatory function depends on the level of secretion of the luteinizing hormone controlled by the hypothalamus (Wisnieski et al., 2019). Thus, violations of reproductive function of cows with high milk production are primarily associated with increased free radical oxidation activity, as well as low NO concentration.

As evidenced by the data of both domestic and foreign researchers, pregnancy, the subsequent parturition and the postpartum period in all mammals are accompanied by significant changes in metabolism, up to and including the subclinical forms of its disruption. At the same time, the most vivid picture of the intensity of metabolic processes takes shape during the final stage of pregnancy and in the early postpartum period (Nezhdanov, 2008), which was also confirmed by our research.

A substantial percentage of cows (5-20\%) had metritis in early lactation. Normally, metritis is diagnosed in 15-20\% of cows at week 5 postpartum and subclinical endometritis is found in $15-50 \%$ of cows 4 to 8 weeks after giving birth. These conditions may be associated with a decrease in reproductive function during this period (Pascottini et al., 2019).

Additionally, within the framework of the discussed problems in the physiology and pathology of animal reproduction, special attention was paid to the problem of oxidative stress, which refers to the oxidative modification of proteins and lipids, accompanied by excessive accumulation of free radical oxidation products. FRO is considered one of the dominant metabolic processes occurring spontaneously at the cellular level, ensuring proper regulation of oxygen conversions in the body as well as metabolism of proteins, nucleic acids, lipids, carbohydrates. These processes are the basis of the plasticity and energy supply in the function of the cell and the body as a whole both in its normal state and during the implementation of adaptive reactions (Halliwell et al., 1992; Shoham et al., 2008). Unfortunately, in many cases, when the balance between the formation of pro-oxidants and the functioning of the antioxidant system is disturbed in the body, especially when exposed to various exogenous stressors, the formation of free radicals can become uncontrolled, causing a disruption of cellular respiration and can lead to multiple adverse effects, including the improper functioning of the reproductive organs (Tamanini et al., 2003). Our findings also indicate the leading role of lipid peroxidation and functional insufficiency in the antioxidant defence system during the development of oxidative stress during pregnancy and parturition. However, most researchers consider the development of oxidative stress in terms of normal and pathological conditions. Our research has 
shown that changes occurring in the LPO-AOD system directly correlate with the severity of a pathological process and have certain differences in their levels depending on the type of obstetric pathology. At the same time, these changes begin to manifest during pregnancy, several months before the expected parturition, which underlines their scientific importance in the possible prediction in the development of various nosological forms of obstetric pathology.

\section{Conclusion}

Among the examined factors, the most susceptible ones were the malonic aldehyde content, the vitamin $\mathrm{E}$ content and the level of catalase activity. Healthy cows were found to have higher levels of malonic aldehyde, vitamin $\mathrm{E}$ and catalase activity than those with some kind of inflammatory health disorder (Tables 3 and 4). Thus, cows that are at risk of developing obstetric pathology tend to show a decrease in the functional potential of the AOD system as well as an accumulation of LPO products as early as two months before parturition. Obstetric pathology during and after parturition develops against the background of highintensity free radical lipid oxidation and reduced activity of the AOD system. These processes are especially prominent and long lasting in animals with postpartum endometritis.

The observed differences in the LPO-AOD systems in cows with normal and pathological progression of the postpartum period indicate that the initial aetiology and pathogenesis of diseases in pregnant cows, parturient complications and functional deficiency of the AOD system during the postpartum period are accompanied by the accumulation of toxic products of lipid peroxidation and metabolic disorders in the animals. Therefore, we can recommend the reported blood parameters as indicators of the development of oxidative stress during pregnancy and, consequently, as having predictive capabilities of obstetric pathology in high-yielding cows.

\section{Funding Information}

This research did not receive any specific grant from funding agencies in the public, commercial, or not-forprofit sectors.

\section{Author's Contributions}

All authors equally contributed in this study.

\section{Ethics}

The authors declare that the work is written with due consideration of ethical standards.

\section{References}

Dobson, H., \& Smith, R. F. (2000). What is stress and how does it affect reproduction?. Animal reproduction science, 60, 743-752.

Halliwell, B. A. R. R. Y., Gutteridge, J. M., \& Cross, C. E. (1992). Free radicals, antioxidants and human disease: where are we now?. The Journal of laboratory and clinical medicine, 119(6), 598-620.

Havekes, C. D., Duffield, T. F., Carpenter, A. J., \& DeVries, T. J. (2020). Effects of wheat straw chop length in high-straw dry cow diets on intake, health and performance of dairy cows across the transition period. Journal of dairy science, 103(1), 254-271.

Karpenko, L.Y., N.V. Pilaeva, R.M. Vasilyev and S.V. Vasilyeva. 2018. Comparative assessment of the dynamics of the main matablic indicators in cows with different milk production. Regulatory issues in veterinary medicine, 3: 190-192.

Kireev, I. V., Orobets, V. A., Sevostyanova, O. I., Shakhova, V. N., \& Agarkov, A. V. (2018). Prospects of using antioxidant drugs for the treatment and prevention diseases of farm animals. Research Journal of Pharmaceutical, Biological and Chemical Sciences, 9(5), 2031-2036.

Kunwar, A., \& Priyadarsini, K. I. (2011). Free radicals, oxidative stress and importance of antioxidants in human health. Journal of Medical \& Allied Sciences, 1(2), 53.

LeBlanc, S. (2010). Monitoring metabolic health of dairy cattle in the transition period. Journal of reproduction and Development, 56(S), S29-S35.

Mezzetti, M., Minuti, A., Piccioli-Cappelli, F., \& Trevisi, E. (2020). Inflammatory status and metabolic changes at dry-off in high-yield dairy cows. Italian Journal of Animal Science, 19(1), 51-65.

Nezhdanov, A. G. (2008). Bolezni organov razmnozheniya $\mathrm{u}$ krupnogo rogatogo skota $\mathrm{v}$ svete sovremennykh dostizheniy reproduktivnoy endokrinologii i patobiokhimii [Diseases of the reproductive organs in cattle in the light of modern advances in reproductive endocrinology and pathobiochemistry]. Sovremennyye problemy diagnostiki. lecheniya i profilaktiki infektsionnykh bolezney zhivotnykh i ptits, 2, 350-364.

Nezhdanov, A. G., \& Dashukaeva, K. G. (1999). Fetoplacental insufficiency and its prevention in cows. Veterinary medicine, (7), 6-11.

Pascottini, O. B., Carvalho, M. R., Van Schyndel, S. J., Ticiani, E., Spricigo, J. W., Mamedova, L. K., ... \& LeBlanc, S. J. (2019). Feed restriction to induce and meloxicam to mitigate potential systemic inflammation in dairy cows before calving. Journal of dairy science, 102(10), 9285-9297. 
Pascottini, O. B., Leroy, J. L., \& Opsomer, G. (2020a). Metabolic Stress in the Transition Period of Dairy Cows: Focusing on the Prepartum Period. Animals, 10(8), 1419.

Pascottini, O. B., Probo, M., LeBlanc, S. J., Opsomer, G., \& Hostens, M. (2020b). Assessment of associations between transition diseases and reproductive performance of dairy cows using survival analysis and decision tree algorithms. Preventive Veterinary Medicine, 176, 104908.

Pezeshki, A., Capuco, A. V., De Spiegeleer, B., Peelman, L., Stevens, M., Collier, R. J., \& Burvenich, C. (2010). An integrated view on how the management of the dry period length of lactating cows could affect mammary biology and defence. Journal of animal physiology and animal nutrition, 94(5), e7-e30.

Safonov, V. A., Nezhdanov, A. G., Retsky, M. I., Shabunin, S. V., \& Bliznetsova, G. N. (2014). Free radical lipid oxidation and reproductive health of cows. Agricultural Biology, (6 (eng)).
Sheldon, I. M., Lewis, G. S., LeBlanc, S., \& Gilbert, R. O. (2006). Defining postpartum uterine disease in cattle. Theriogenology, 65(8), 1516-1530.

Shoham, A., Hadziahmetovic, M., Dunaief, J. L., Mydlarski, M. B., \& Schipper, H. M. (2008). Oxidative stress in diseases of the human cornea. Free Radical Biology and Medicine, 45(8), 1047-1055.

Sordillo, L. M., \& Mavangira, V. (2014). The nexus between nutrient metabolism, oxidative stress and inflammation in transition cows. Animal Production Science, 54(9), 1204-1214.

Tamanini, C., Basini, G., Grasselli, F., \& Tirelli, M. (2003). Nitric oxide and the ovary. Journal of Animal Science, 81(14_suppl_2), E1-E7.

Wisnieski, L., Norby, B., Pierce, S. J., Becker, T., Gandy, J. C., \& Sordillo, L. M. (2019). Predictive models for early lactation diseases in transition dairy cattle at dry-off. Preventive veterinary medicine, 163, 68-78. 